\title{
Development of EFL learners' writing attitude through Mobile Instant Messaging Application (MIMA)
}

\author{
Yoon, Tecnam $\bowtie \Delta$ \\ Chuncheon National University of Education, Republic of Korea (yoon@ cnue.ac.kr)
}

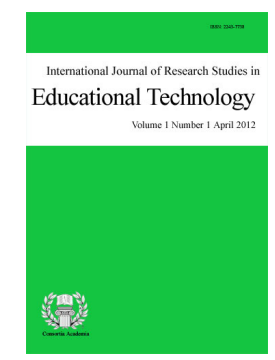

ISSN: $2243-7738$

Accepted: 13 August 2017 Online ISSN: 2243-7746

OPEN ACCESS

\section{Abstract}

With the fast development of computer-assisted learning, a variety of computer mediated communication tools have been used in learning. As a kind of modern technology, MIMA (Mobile instant messaging application) is familiar recent years in most e-learning environments. The purpose of this study is to investigate the effectiveness of MIMA and learners' attitudes and perception about MIMA. Using a mixed method, the survey and interview were employed to meet its intention. 32 junior students in the university participated in this research for 15 weeks. Results show the participants affirmed the positive effect in English learning through MIMA. MIMA played an important role in improving the students' interests. About half of participants' attitudes were positive about using MIMA to engage in writing English. Based on the interview data, it seemed clear most participants were satisfied with MIMA for their English writing. Through the analysis and discussion of the data, it was found that in general students held a positive view regarding the use of MIMA. Most participants expressed they liked using MIMA when learning outside the school. Compared with the traditional English writing class, using MIMA was much more interesting, making students more active and attentive. This implies that language teachers can utilize MIMA as a sub-teaching material.

Keywords: writing practice; learning attitude; mobile messaging application; motivation 


\section{Development of EFL learners' writing attitude through Mobile Instant Messaging Application (MIMA)}

\section{Introduction}

Without a doubt, we are confronted with dozens of technologies in a daily life. For instance, we use smartphone, check emails and messages, and make an online reservation with a few simple clicks. Education and language learning is not an exception. Due to the rapid development of ICT (information communication technology), everyone can learn using electronic devices. Since ICT has shown its potential to transform education, e-learning became more popular to support and enhance learning process. It is clear today that ICT-based learning began developing and obtaining importance, and e-learning became the fundamental component of all educational activities in and outside the classroom. It is currently changing the ways schools teach and students learn. Through e-learning, students are able to study synonymously with digital devices, regardless of the time and space. CBI (computer-based instruction), WBL (web-based learning), distance learning, online learning, mobile learning, or virtual learning are good examples of e-learning.

When it comes to a foreign language education, CALL (computer-assisted language learning) has been regarded to increase learning potential by many researchers (Levy, 2000; Liou, 2004; Singh, 2010). CALL embraces a wide range of ICT applications and approaches to teaching and learning. It is considered a tool that helps language teachers to facilitate the learning process. Also, it has been used to reinforce what has already been learned in the class, or as a remedial tool to help learners who require additional support.

Today, out of interactive CALL programs, mobile learning (M-learning) has gained importance, since it is flexible and convenient in that it is accessible from virtually anywhere and anytime. Crompton (2013) defined m-learning as learning across multiple contexts, through social and content interactions, using personal electronic devices. One of the most distinctive features of m-learning lies on the mobility of the learner, interacting with portable technologies. Using smartphones, or tablet PCs, learners can learn virtually anywhere an internet signal is available. Mobile instant messaging application (hereafter ' $M I M A$ ') is one option for both language teachers and learners to employ to foster interactive and collaborative learning. MIMA is basically a messaging application which uses instant messaging via mobile devices, employing various technologies such as sending text messages and making free calls over the internet without incurring a charge from their cellular carriers. In Korea, Kakao Talk is the dominant mobile messaging app which enables users to have free one-on-one and group chats anywhere, as well as free voice and video calls available domestically and internationally. The main communication features are all free of charge once connected to WiFi, 3G, or LTE.

In this sense, MIMA can one of the most powerful tools which can facilitate language learning, let alone social networking with others. Therefore, MIMA was selected for this study, as a key medium in English class. In fact, it is very difficult to learn and master a new foreign language, because its system, grammatical structures, pronunciation, spelling and so on, may be all different from L1. In particular, many of the ELLs (English language learners) in EFL (English as a foreign language) context struggle to write in English when expressing their ideas and thoughts. As writing is considered as a productive skill like speaking, it takes lots of time and instruction in order to equip enough competency. However, no matter how much writing instruction is emphasized, ELLs in the EFL situation such as Korea, tend to underestimate it with spending less time practicing writing. Thus, this research study was designed to explore the effectiveness of the use of MIMA, such as Kakao Talk in writing practice, and to verify ELLs' responses using MIMA for improving writing skills. 


\section{Review of Literature}

\subsection{Today's Learning and Technology}

Today, it is not possible for us to imagine living a life without any kinds of technologies. Technology plays a vital key that has changed social, cultural, educational, political values of our life. The advent of the internet made world a small and close place where people can easily communicate each other and receive information in no time, regardless of geography. Ways of life of human beings have greatly changed due to the appearance of the internet, and it is no longer unfamiliar with online shopping, online banking, online booking, online reservation or something related to online. Education is also part of it. Technological developments open wide range alternative choices to gain benefit for people's life (Forcier, 1996). ICT has influenced the education and students, by providing alternatives learning styles and learning in a creative way (Forcier, 1996). In other words, it became possible to learn new things without attending a lecture to a physical classroom. Learners today got to have alternative options to study what they want to know at home, at workplace or even at running subway. The great impact about technology brought individuals to be more self-paced and autonomous, as opposed to the traditional learning style (Vilmi, 1999; Yoon, 2016). In addition to this, students can get various capacities and properties while they are engaging in learning with technology. The use of computer-mediated communication is expanding rapidly around the world in which time and space are not limited. Social media is one of the items most people use everyday life to interact with others. Facebook, Twitter, and Instagram are good examples of social media, which are dedicated to community-based input, interaction, content-sharing and collaboration. It has also become an important part of the process of language learning (Tschirner, 2001). According to Liou's study (2004), most students often had communicated or chatted through online at home, or outside the classroom. Plus, many educators and researchers have already argued that the technology-integrated language teaching and learning has potentials because students' learning and motivation would be promoted for a certain reason (Elias, 2011; Lin, 2004; Wang, 2006, Yoon, 2013).

Language learners would use the technology to communicate synchronously and asynchronously with teachers or others for practicing and supplementing their language skills. Chou (2001) evaluated various technologies used in an online course, and found out that the more frequently a technology was used, the more comfortable online students became with it. Likewise, Liu (2003), and Moallem (2003) discovered that students had more success with technology if they were given the opportunity to practice both before and during the course. The instructor's timely feedback could positively affect the adaptation process (Chou, 2001). In terms of students' attitudes toward an online degree program, Young and Norgard (2006) observed that younger students were positively disposed toward online discussions. A study of communication pattern analyzed by using or not using instant messaging (IM), showed younger students were more likely to use a variety of technology for online communication (Nicholson, 2002). Liu (2003) reported that the success of discussions in online classes depended on whether the technology used to support students' communication met their learning needs and expectations. Likewise, the increased use of newer technology, such as simulation, weblogs, in academic settings is suggested to positively affect students' desire to use them (Jabbour, 2013). Mendoza (2014) analyzed students' attitudes and expectations about the use of video conferencing for learning, and their perceptions about the quality of learning results.

A variety of technology have been used in online learning environments to facilitate learning and communication among adult learners. Garrison and Clevelend-Jones (2005) proposed that creating a community of inquiry can foster a sense of deeper learning among learners. The extent to which learners can construct meaning through sustained communication depends on how the communication is restricted or encouraged by the medium (Looi \& Wang, 2014). Pre-service students who used an online discussion forum to interact acknowledged that effective asynchronous online communications required them to carefully construct their messages. Group discussions proved to be productive in the sense that students could focus on course related discussions, learn from each other, and finish a group project (Vonderwell, 2003). Likewise, qualitative analysis 
Yoon, T.

of messages posted to discussion forums and synchronous chat sessions of an online course, revealed that participants could do problem-solving, peer-coaching, and making links between course material and other useful resources (Ahmad \& Orion, 2010; Crescente \& Lee, 2011; Shin \& Kang, 2015).

\subsection{E-Learning and M-Learning}

One of the merits of e-learning can be learners' autonomy, that is e-learning can be conducted entirely with computer by self-paced. This made a tremendous change compared to the traditional classroom setting. E-learning focuses more on the learner rather the instructor. More information flows from the student to the instructor. As a result of learners' constructing their own learning, they are considered to be more active. This type of active learning forces instructors to be guides on the side of the learner (Cook \& Pachler, 2012). Learners in e-learning have more responsibility for their learning, and instructors spend much more time providing resources than delivering content (Grad, Pluye, Meng, Segal, \& Tamblyn, 2005). Traditional classes and online classes often use different technologies, types of media, and forms of interaction. With its wider range of technologies, media and forms of interaction, e-learning can help instructors meet a broader range of students' needs (Wang, 2006). It is very clear that the Internet-based instruction has been dominant in e-learning era. Figure 1 as shown below indicates how e-learning has connected into other components, and also intertwined with others.

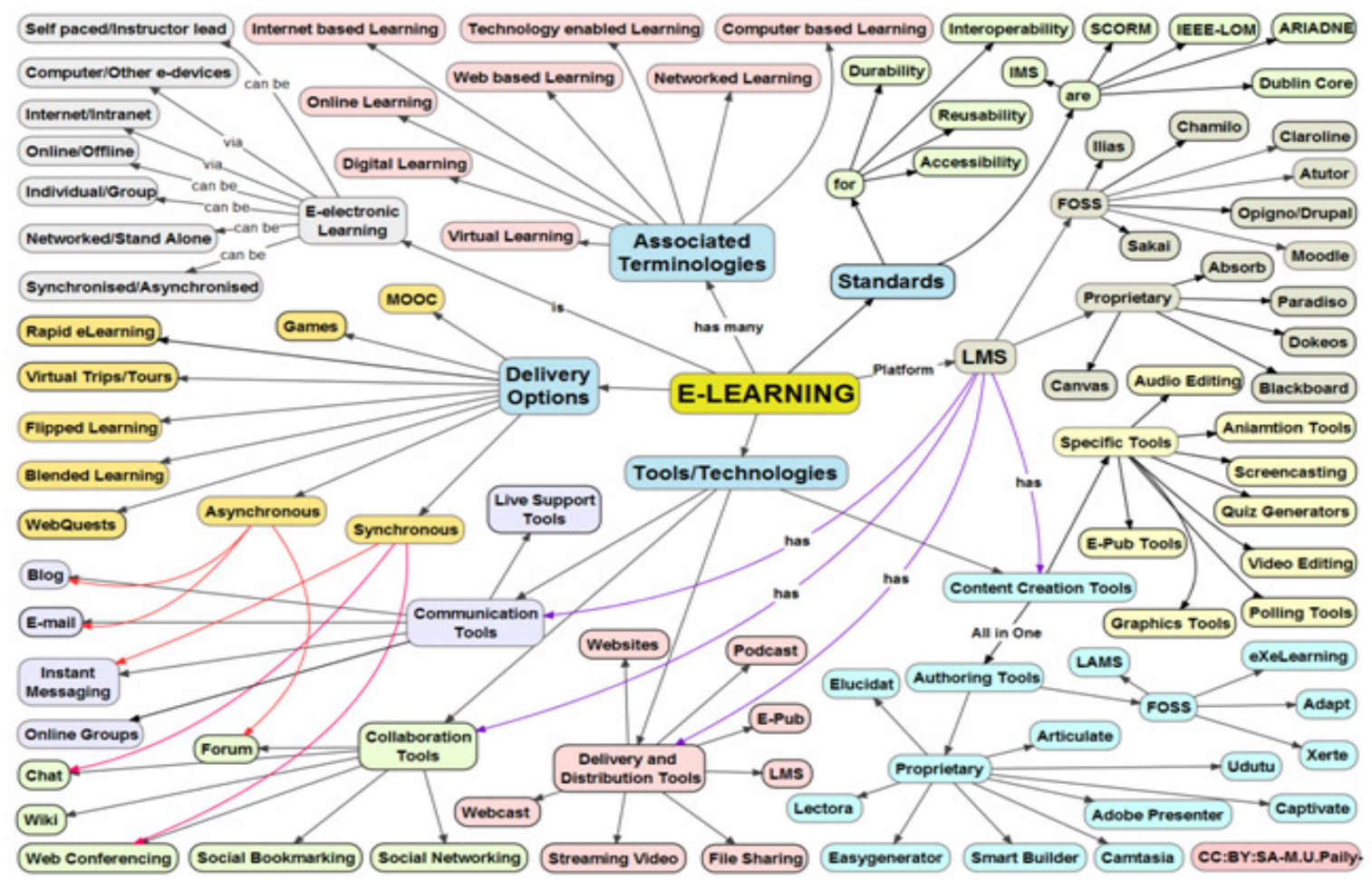

Figure 1. Organization of E-learning

Yet, nearly in the past ten years, there has been growing interest in the role of mobile devices in promoting education in that mobile devices take advantage over PCs with respect to educational contents. One of the main limitations of computer-centric learning was the lack of varied and robust learning software programs. However, due to the rapid growth of mobile educational applications from 'Google Play', or 'App Store', a mobile device has greatly expanded alternative opportunities for learners. Fabian, et all (2016) stressed that apps are an important and growing medium for providing educational content to children, both in terms of their availability and popularity. In fact, many apps are provided in a game-like environment, it showed the effectiveness in promoting learning motivation, making learners engaged than traditional learning pedagogies (Singh, 2010). 
Mehdipour and Zerehkafi (2013) described how students today learn through m-learning shown as below at Figure 2.

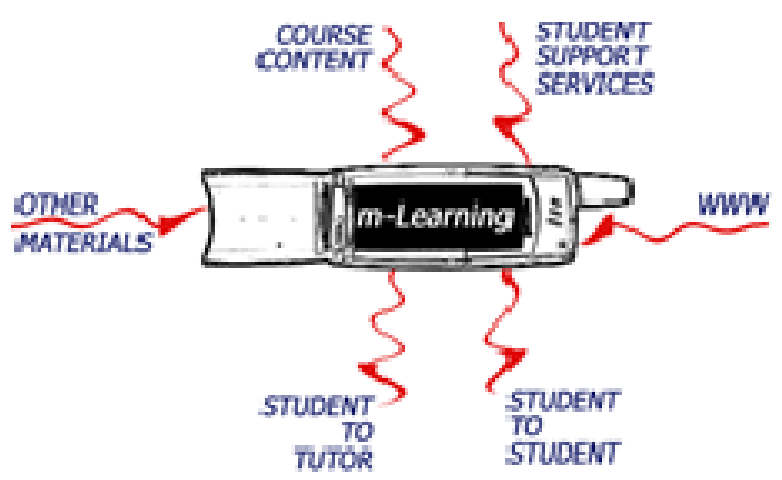

Figure 2. Wireless virtual learning environment of tomorrow

Table 1

Comparison between e-learning and m-learning (Mehdipour \& Zerehkafi, 2013)

\begin{tabular}{|c|c|c|}
\hline Subject & E-Learning & M-Learning \\
\hline place & lecture in classroom or internet labs & learning anywhere, anytime \\
\hline \multirow{2}{*}{$\begin{array}{l}\text { pedagogical } \\
\text { change }\end{array}$} & more text- and graphics based instructions & $\begin{array}{l}\text { more voice, graphics and animation based } \\
\text { instructions }\end{array}$ \\
\hline & lecture in classroom or in internet labs & learning occurring in the field or while mobile \\
\hline \multirow{4}{*}{$\begin{array}{l}\text { instructor to } \\
\text { s tudent } \\
\text { communication }\end{array}$} & time-delayed & instant delivery of e-mail or SMS \\
\hline & passive communication & instant communication \\
\hline & asynchronous & synchronous \\
\hline & scheduled & spontaneous \\
\hline \multirow{8}{*}{$\begin{array}{l}\text { student to } \\
\text { s tudent } \\
\text { communication }\end{array}$} & face-to-face & flexible \\
\hline & audio-teleconference communication & audio- and video-teleconference possible \\
\hline & e-mail-to-e-mail & $27 / 4$ instantaneous messaging \\
\hline & private location & no geographic boundaries \\
\hline & travel time to reach to internet site & $\begin{array}{l}\text { no travel time with wireless internet } \\
\text { connectivity }\end{array}$ \\
\hline & dedicated time for group meetings & flexible timings on $24 / 7$ basis \\
\hline & poor communication due to group & rich communication due to one-to-one \\
\hline & consciousness & communication, reduced inhibitions \\
\hline \multirow{6}{*}{$\begin{array}{l}\text { feedback to } \\
\text { student }\end{array}$} & one-on-one basis possible & one-on-one basis possible \\
\hline & asynchronous and at times delayed & both asynchronous and synchronous \\
\hline & mass/standardized instruction & customized instruction \\
\hline & benchmark-based grading & performance \& improvement-based grading \\
\hline & simulations \& lab-based experiments & real-life cases and on the site experiments \\
\hline & paper-based & less paper, less printing, lower cost \\
\hline \multirow{6}{*}{$\begin{array}{l}\text { assignments \& } \\
\text { t ests }\end{array}$} & in-class or on computer & any location \\
\hline & dedicated time & 24/7 Instantaneous \\
\hline & restricted amount of time & any amount of time possible \\
\hline & standardized test & individualized tests \\
\hline & usually delayed feedback & instant feedback possible \\
\hline & fixed-length tests & flexible-length/number of questions \\
\hline
\end{tabular}




\begin{tabular}{|c|c|c|}
\hline Subject & E-Learning & M-Learning \\
\hline \multirow{8}{*}{$\begin{array}{l}\text { presentations, } \\
\text { e xams \& } \\
\text { a ssignments }\end{array}$} & theoretical and text based & $\begin{array}{l}\text { practical oriented exams direct on site, } \\
\text { hands-on based }\end{array}$ \\
\hline & observe and monitoring in lab & $\begin{array}{l}\text { observe in the field and monitoring from } \\
\text { remote location }\end{array}$ \\
\hline & class-based presentations & $\begin{array}{l}\text { one-on-one presentations with much richer } \\
\text { communication }\end{array}$ \\
\hline & usually use of one language & $\begin{array}{l}\text { automatic translation for delivery of } \\
\text { instructions in many languages (possible) }\end{array}$ \\
\hline & $\begin{array}{l}\text { mostly individualized, component based group } \\
\text { work }\end{array}$ & simultaneous collaborative group work \\
\hline & paper-based assignment delivery & electronic-based assignment delivery \\
\hline & $\begin{array}{l}\text { hand-delivery of assignments at a certain place } \\
\text { and time }\end{array}$ & e-delivery of assignments at any place and time \\
\hline & instructor's time used to deliver lectures & $\begin{array}{l}\text { instructor's time used to offer individualized } \\
\text { instructions and help }\end{array}$ \\
\hline
\end{tabular}

Besides, many researchers have found out the distinct benefits that mobile devices offer as an effective educational tool (Sharples, 2000). Kim, Rueckert, Kim, and Seo (2013) has shown mobile devices have the potential in learning to widen access and supplement education. According to Looi and Wong (2014) "the portability and versatility of mobile devices has significant potential in promoting a pedagogical shift from didactic teacher-centered to participatory student-centered learning". According to Kim et al. (2013), m-learning has potential and advantages as follows:

$>$ Portability: mobile device the size of the palm, or toy-like

$>\quad$ Joy in learning: content in the form of short stories, cartoons and songs the children sing together

$>$ Ease of use: anyone can learn to operate the basic functions of a mobile learning device in a matter of minutes

$>$ Durability: highly resistant to shock and dust

$>$ Maintenance: it only needs recharging.

\subsection{Synchronous learning and Asynchronous learning}

E-learning may either occur synchronously, or asynchronously at large. Synchronous learning occurs in real-time, between individuals interacting at the same time, while asynchronous learning is self-paced and allows participants to engage in the exchange of ideas or information not at the same time. In synchronous learning, communication among each individual occurs at the same time, and information is instantly processed. As a two-way communication method, common examples are online face-to-face discussion, online live-stream lecture, instant mobile messaging apps, and chat rooms where everyone is online and working collaboratively at the same time. MIMA is one of the most familiar types in the synchronous learning, and it can be utilized widely in learning. Asynchronous learning, on the other hand, does not always occur in real-time. Asynchronous learning may use technologies such as email, blogs, wikis, LMSs (learning management system), and MOOC (massive open online course) where participants cannot be online at the same time. It provides learners with more flexibility, time and autonomy. Simply put, learners can access to an e-learning environment at any time to process their learning progress. In terms of LMS, asynchronous e-learning also offers two-way communication between learners and instructors, and collaborative communication among learners themselves. Below is a comparison between synchronous and asynchronous learning. 
Table 2

Comparison between synchronous and asynchronous learning

\begin{tabular}{llll}
\hline \multirow{2}{*}{ type } & \multicolumn{2}{c}{ place } & graphic \\
\cline { 2 - 3 } & same & different & gan \\
\hline
\end{tabular}

$\begin{array}{llll}\text { Synchronous } & \text { webinar, video } \\ \text { live(face-to-face) lecture, } & \begin{array}{l}\text { conferencing, } \\ \text { virtual world, } \\ \text { simulation }\end{array}\end{array}$

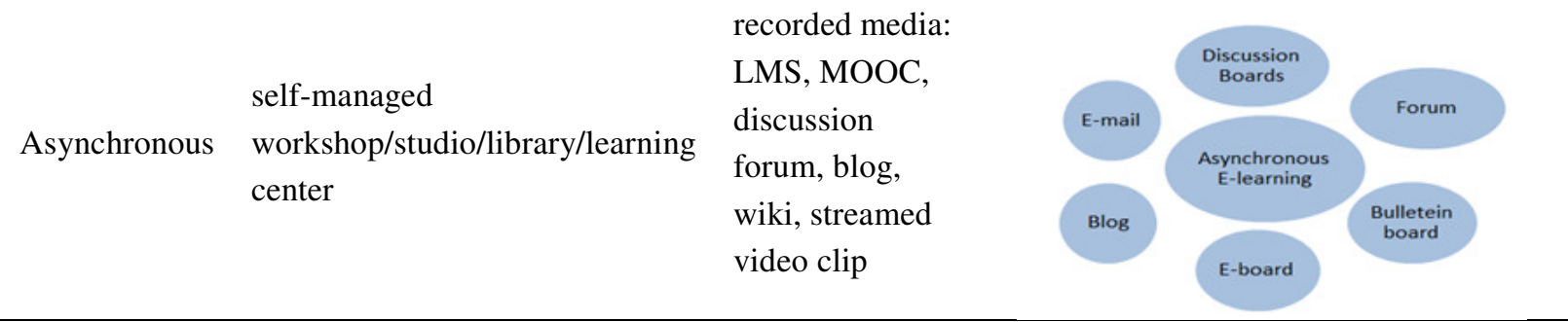

\subsection{Mobile Instant Messaging Application(MIMA)}

Mobile Instant Messaging Application (MIMA) is a vehicle to exchange text messages through mobile devices in real-time. MIMA allows users to interact with one another through text or voice messages. Thanks to ICT development, this has become very popular as here, everything is performed in a faster, more reliable and cohesive manner. MIMA also helps educator and teachers to create subject specific groups for exchange of information and sharing of resources. MIMA, such as Kakao Talk or Line are extensively used by teaching community as reliable communication tool these days. For example, Kakao Talk is by a landslide, the most frequently used messaging app in Korea. It is a free mobile instant messaging application for digital devices and available on iOS, Android and even PC (http://www.kakao.com/main). As of 2015, Kakao Talk had 170 million users (Kim, et al, 2013). The app is also used by $93 \%$ of smartphone users in Korea. In addition to free calls and messages, Kakao Talk users can share diverse content and information including photos, videos, voice messages, and etc. Both one-on-one and group chats are available, as well and there are no limits to the number of people who can join in on a group chat. So, it can be very beneficial to practice writing through Kakao talk because it is not quite as focused on grammar and written English. This allows users to use what they know to communicate, and through reading what they say in reply messages, learn the correct way to say things.

Figure 3. A screenshot of Kakao Talk

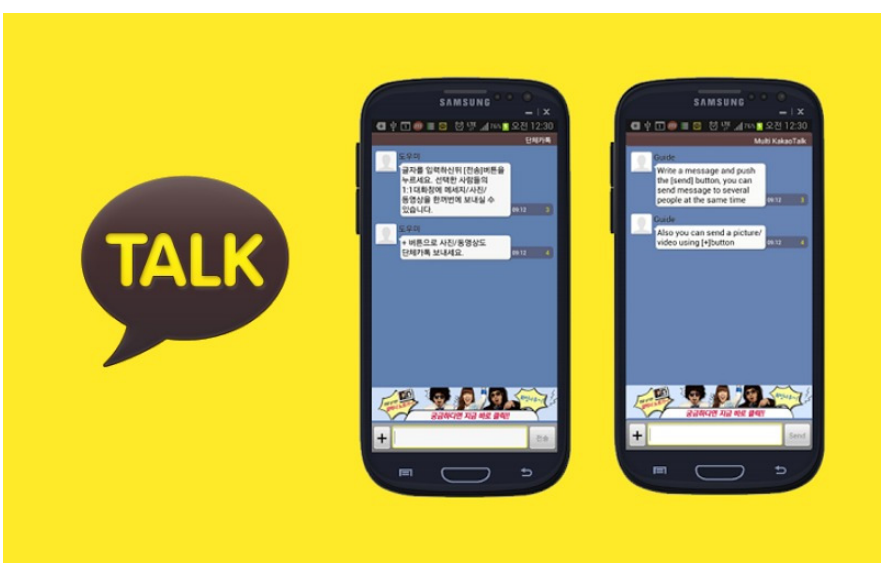


MIMA has been cited widely to support socialization and community building in online learning environments (Sharma \& Kitchens, 2004). Chou (2001) argued that synchronous tools such as MIMA afforded higher levels of social presence, and was preferred by students as a means of developing a sense of community (Chou, 2001). Nicholson (2002) noted that MIMA resulted in a big influence on online students' sense of community, as it facilitated informal communication not only among students, but also between students and their instructor. What's more, in comparison with messages that had been well thought out and posted on the discussion forum, the spontaneous nature of MIMA facilitated more informal communication threads (Nicholson, 2002).

A study of Chang, Chen, and Hsu (2011) explored learning performance of students using different learning strategies. 103 students of 6th grade participated the study, divided into 3 groups with the traditional learning method, the traditional learning method and webquest, and only webquest, respectively. The result revealed that a group using PDAs, tablet PCs and smartphones improved learning performance than the other two groups. These were also found to enhance creative thinking, perspective and learning.

While, a study of Dos (2014) revealed that university students' academic achievement and metacognition awareness were escalated after applying m-learning. Taleb, Ahmadi, and Musavi (2015) emphasized that mobile technology would open the door for next generation, so that learning could occur in anytime, anywhere in a variety of learning contexts. Jabbour (2013) found out that a mobile phone affected positively in students' learning attitude change when used for educational purposes. Their prospects of mobile phones' effectiveness brought a positive impact on their learning outcomes.

Bidaki, Naderi, and Ayati (2013) also argued that the use of mobile learning method had quite significant impact on students' academic achievement and learning attitude. Because mobile-based learning activities helped learners engaged in the learning process a lot better, compared to the traditional one, intrinsic motivation towards further learning aroused, helping them active learners (Wang, Shen, Novak, \& Pan, 2009). Furthermore, Hsu (2013) revealed that mobile-assisted language learning (MaLL) can be a potential tool for language teaching and learning in an EFL setting. Behera (2013) listed the advantages of using mobile learning tools as follows:

$>\quad$ Increased mobility: Learning is not restricted to fixed locations any more. Mobile devices allow learners to access learning content and learning interactions anywhere, such as factories, museums, hospitals, shopping malls, cafes and outdoor areas;

$>$ Time-saving: People can now study when they are commuting and traveling;

$>$ Environmental-friendly: It is amazing to find out how much information a mobile device can carry despite its light weight. Less printing is required;

$>$ Interactive: Mobile technology enables students to closely link with their peers, teachers, distant partners, and even interest groups worldwide;

$>\quad$ Use of relatively inexpensive everyday technologies;

$>\quad$ Much better opportunities to obtain skills at one's own pace in such a way that may be missing if using shared computer sets or trusting somebody else's equipment;

$>$ Good support for preferred modes of interaction, e.g. accessing audio content or participating in social networks on the move;

$>\quad$ Catering for interests beyond what is provided in class, through access to additional content such as podcasts or free learning materials (e.g. Open Learn);

$>\quad$ Handheld devices are often an everyday part of business, so learning can contribute directly to enhancing employability, life skills and work practices;

$>\quad$ Opportunities for learners to give immediate feedback on their learning experience;

$>\quad$ Better assessment and diagnosis of learning problems as they occur;

$>\quad$ Psychological support for those at risk of dropping out, through social networks or personal guidance 
from a mentor;

$>$ Learning materials can become accessible to a larger audience, through podcasts, mobile applications, blogs and e-books, which are seen by potential students.

\section{Methods}

This current research study aims to investigate the effectiveness of MIMA in EFL writing, and EFL learners' perceptions on MIMA. Below are two main research questions, and in order to answer them, a mixed-method method was chosen to meet its intention.

$>\quad$ What could be the advantages and disadvantages in using MIMA?

$>\quad$ Are there any changes in terms of students' learning attitude and perception on MIMA?

\subsection{Research settings}

The research site was a national university located in the mid-sized city in Gangwon province, Korea. There were approximately 1,500 students enrolled in the undergraduate program, and 12 majors in this university. Regardless of their major, all of the students were required to take basic English (pronunciation, grammar, and classroom English) as a compulsory course. In department of English education, English courses were offered to students which included basic English, reading and writing, listening and speaking, oral English, grammar, literatures, and so on. For this research, A total number of 32 junior students from English department participated in this study. All of them majored English education and were taking English writing methodology class as of Spring 2016. Their overall English proficiency was above intermediate. The course took a process writing approach with the goal to help students to compose clear and well-reasoned prose. The class met two-hour every Wednesday for 15 weeks.

\subsection{Instruments}

In order to investigate the effectiveness of MIMA and learners' attitudes and perception about MIMA, a survey made by the researcher was distributed twice as a pre- and post-one. The survey consisted of 12 questions to verify the subjective attitude towards writing English with MIMA. It had 2 parts asking participants' personal information about MIMA and next section was composed of each participant's own perception about using MIMA. Each item statement in the survey used a 5-point Likert scale: (1) strongly disagree (5) strongly agree. Participants were contacted and notified about the survey via Kakao Talk. The survey was also administered through Kakao Talk. In addition to the survey, the interview was conducted and completed through face-to-face communication and conducted with four participants in total. The interview was recorded, and saved on the researcher's smartphone. The interview was conducted twice during the research in the native language of the participants.

\subsection{Data collection and analysis}

When beginning of the study, students were also asked to specify the attitude of their writing in English through MIMA by participating in a survey. The reason for this aimed to grasp students' overall thoughts and learning attitude on MIMA in English writing. Data from the interview was intended to comprehend their general thoughts on MIMA, so those were analyzed in combination with the results of the survey. In terms of data analysis, firstly, descriptive statistics was administered to analyze the survey results. This data is calculated and then analyzed in Microsoft Excel 2016 and IBM SPSS 24.0 for Windows was employed for descriptive statistics (frequency, percentage, and mean). The qualitative data arising from the interview was analyzed by organizing, summarizing, and categorizing. 


\section{Findings}

After each instrument was completed, the researcher accessed the completed data. This study involved the use of mix-methods, with survey and interviews. The data collected from the survey was objectively analyzed and the data from the interviews applied to deepen the understanding of MIMA amongst Korean EFL learners of English.

\subsection{Results of survey}

Results of the survey were mainly gathered from the descriptive analysis of students' English learning with MIMA. As shown in Table 3, the mean value of responses from 32 participants to four categories was analyzed. Among them, the average mean of the students' attitudes and responsibility to MIMA was the highest (mean=4.23), that means learning using MIMA, as an autonomous learning resource, can help students to provide their learning responsibilities.

\section{Table 3}

Average means across categories of using MIMA

\begin{tabular}{llc}
\hline \multicolumn{1}{c}{ Categories of using MIMA for learning } & $N$ & $M$ \\
\hline learners' attitudes and responsibilities towards learning with MIMA & 32 & 4.23 \\
Learner choices when using MIMA & 32 & 4.05 \\
Process monitoring when using MIMA & 32 & 3.32 \\
Effectiveness of learning with MIMA & 32 & 2.85 \\
\hline
\end{tabular}

\subsection{Results of students' attitudes on MIMA}

Questions from 5 to 8 on the learning attitudes on MIMA were asked whether it could be helpful to learn and improve their written English. As the next Table 4 shows, 61.4\% students answered they like learning English with the assistance of MIMA, whereas only a few of them, 11.1\%, were not fond of learning English via learning with a messaging application. For learning with MIMA, as asked by question \#6, results showed 55.8\% participants' satisfaction for MIMA in learning. The results indicate that most of the participants were interested in using MIMA for learning and had positive attitudes towards it.

\section{Table 4}

Students' attitude toward learning with MIMA

\begin{tabular}{|c|c|c|c|c|c|}
\hline \multirow[b]{2}{*}{ Question-statement } & \multicolumn{5}{|c|}{ Likert scale (1-5) \% } \\
\hline & $\begin{array}{l}\text { strongly } \\
\text { disagree }\end{array}$ & disagree & $\begin{array}{c}\text { neither } \\
\text { disagree } \\
\text { nor agree }\end{array}$ & agree & $\begin{array}{l}\text { strongly } \\
\text { agree }\end{array}$ \\
\hline $\begin{array}{l}\text { I think learning English with a help of } \\
\text { MIMA is helpful. }\end{array}$ & 5.4 & 5.7 & 27.5 & 44.7 & 16.7 \\
\hline I like using MIMA to study English. & 11.5 & 5.5 & 27.2 & 49.7 & 6.1 \\
\hline A learning experience using MIMA is good. & 16.2 & 33.5 & 28.2 & 16.7 & 5.4 \\
\hline $\begin{array}{l}\text { I think writing practices while using MIMA } \\
\text { can improve. }\end{array}$ & 5.8 & 12.1 & 22.2 & 30.7 & 29.2 \\
\hline
\end{tabular}

\subsection{Results of students' satisfaction of MIMA}

Table 5 shows that nearly $61 \%$ of the students were satisfied with their achievement in learning English through MIMA. And $11 \%$ of the students were not sure about the achievement, whilst $28 \%$ were not satisfied 
with the achievement in learning through MIMA. During the period of using MIMA, around 40\% of participants realized the importance of English language learning with mobile devices, and became interested in this kind of learning.

Table 5

Students' attitude toward learning with MIMA

\begin{tabular}{|c|c|c|c|c|c|}
\hline \multirow[b]{2}{*}{ Question-statement } & \multicolumn{5}{|c|}{ Likert scale (1-5) \% } \\
\hline & $\begin{array}{l}\text { strongly } \\
\text { disagree }\end{array}$ & disagree & $\begin{array}{c}\text { neither } \\
\text { disagree } \\
\text { nor agree }\end{array}$ & agree & $\begin{array}{l}\text { strongly } \\
\text { agree }\end{array}$ \\
\hline $\begin{array}{l}\text { MIMA provides me with a good } \\
\text { environment. }\end{array}$ & 11.5 & 16.2 & 11.5 & 38.4 & 22.4 \\
\hline $\begin{array}{l}\text { MIMA fulfills my need for frequent } \\
\text { checking through peer feedback. }\end{array}$ & 16.2 & 23.4 & 31.2 & 11.4 & 17.8 \\
\hline $\begin{array}{l}\text { MIMA makes me develop digital literacy } \\
\text { skills as well as writing. }\end{array}$ & 10.8 & 15.7 & 20.1 & 46.2 & 7.2 \\
\hline $\begin{array}{l}\text { MIMA makes me engaged in writing with } \\
\text { immediate feedback. }\end{array}$ & 20.1 & 25.4 & 32.8 & 12.5 & 9.2 \\
\hline
\end{tabular}

\subsection{Results of students' interview}

In order to grasp a deeper understanding of participants' benefits and attitudes towards MIMA, a face-to-face interview was administered with 4 focal students twice through the study. The results of this interview indicate that a learning experience with MIMA can develop learner autonomy and promote their learning motivation. Below are a few excerpts from focal participants, which were recorded in the Korean language and then translated into the English language later.

A positive attitude towards MIMA learning - Seoung-Kirl ${ }^{1}$ stated in the week \#10, "It was basically fun, and interesting, because I thought, Kakao Talk is used for only communication, not for education. I imagine teachers can give a short essay, reflection and something like that to students, let's say, after reading a short story or watching a short clip. Then, we can check their writing in real-time and provide a timely comment or feedback."

Learners' autonomy and flexibility - Kyeong-Jun stated in the week \#14, “To me, it was not like learning, but a daily routine, like send messages to friends. I did not need any paper or pen to write. What I needed was only my smartphone, and simply, write, send, check and re-check any given comments. I think this could be cool unless we, as a teacher, deal with very academic writing, such as a term paper, because it is flexible and to share and to express my thoughts are important."

Learner centered learning - Kyeongo stated in the week \#14, "I think I can use this in the after-school program as a sub-teaching material. I can give a writing activity to students, and they, as a group, pair or individual, can read something and share their writing in real-time. I also think their learning confidence many be increased, and this will more likely result in more positive learning."

As described above, MIMA offered flexibility allowing participants to boost their own learning goals, arrange their time to complete learning, and assess their learning when convenient. However, there were drawbacks for using MIMA identified. Although MIMA benefited students, it was noted that some problems have emerged. First of all, students have difficulties in having a proper feedback. Feedback was usually provided

\footnotetext{
${ }^{1}$ In this paper, pseudonym was used to hide participants' identity.
} 
Yoon, T.

by the instructor and peers in a real time, but the main focus lay on not the perfect grammar or logical organization, but comprehension. So, many of students had difficulty in finding some grammatical problems. Next, students complained to type letters using their smartphone, because the keypad was quite small compared to PC keyboard. Students, having a tablet PC expressed similar opinion, as well. Lastly, it was frequent that participants lost the signal to access MIMA for some reasons occurred by the weak WiFi.

\section{Conclusions}

\subsection{Summary of the Research}

With the fast development of computer-assisted learning, a variety of computer mediated communication tools have been used in learning. As a kind of modern technology, MIMA was used widely, and all the participants answered that they had used Kakao Talk even before entering a university. In the first part of the survey, most students replied that the main function using MIMA relied on a communicative purpose to chat with friends and they scarcely thought about learning languages with such a tool.

From the results of the survey, the participants affirmed the positive effect in English learning through MIMA. MIMA played an important role in improving the students' interests. And about half of participants' attitudes were positive about using MIMA to engage in writing English. Based on the interview data, it seemed clear most participants were satisfied with MIMA for their English writing. Through the analysis and discussion of the data, it was found that in general students held a positive view regarding the use of MIMA. Most participants expressed they liked using MIMA when learning outside the school. Compared with the traditional English writing class, using MIMA was much more interesting, making students more active and attentive. This implies that language teachers can utilize MIMA as a sub-teaching material when, for instance, they may provide a writing assignment after school.

\subsection{Implications of the research}

According to Hawkins (2001), it takes two years for ELLs to learn a conversation English, but it would take five to seven years for them to gain academic English proficiency. Out of the four language skills (speaking, listening, reading and writing), writing practice, as a productive skill, is considered as a difficult one. Although there has been a lot of research studies conducted previously on how to develop writing skills, it is still complicated to pick up one specific method which may produce the best outcomes. In this sense, MIMA, as an interesting sub-teaching and learning material can play an important role in not only gaining more English writing competence and proficiency, but also escalating learners' motivation and interest. To prove its effectives more in detail, further research studies on how to provide proper feedback, and monitor learning progress should be followed. Plus, those research needs to have more samples and diverse range of learners from elementary school to university.

Acknowledgement: I would like to thank all our valued reviewers who have contributed to the journal. Your constructive comments and feedback made great contribution to the development of this paper. Please accept my deepest thanks for your knowledge, time and continuing efforts.

\section{References}

Ahmad, N., \& Orion, P. (2010). Smartphones make IBM smarter, but not as expected. Training and Development, 64(1), 46-50.

Behera, S. K. (2013). E- and M-learning: A comparative study. International Journal on New Trends in Education and Their Implications, 4(3), 65-78. 
Development of EFL learners' writing attitude through Mobile Instant Messaging Application (MIMA)

Bidaki, M. Z., Naderi, F., \& Ayati, M. (2013). Effects of mobile learning on paramedical students' academic achievement and self-regulation. Future of Medical Education Journal, 3(3), 24-28.

Chang, C. S., Chen, T. S., \& Hsu, W. H. (2011). The study on integrating webquest with mobile learning for environmental education. Computer and Education 57(1), 1228-1239.

https://doi.org/10.1016/j.compedu.2010.12.005

Chou, C. (2001). Formative evaluation of synchronous CMC systems for a learner-centered online course. Journal of Interactive Learning Research, 12(2), 173-192.

Cook, J. \& Pachler, N. (2012). Online people tagging: Social (mobile) networking services and work-based learning. British Journal of Educational Technology, 43(5), 711-725. https://doi.org/10.1111/j.1467-8535.2012.01346.x

Crescente, M. L., \& Lee, D. (2011). Critical issues of M-Learning: design models, adoption processes, and future trends. Journal of the Chinese Institute of Industrial Engineers, 28(2), 111-123. https://doi.org/10.1080/10170669.2010.548856

Crompton, H. (2013). A historical overview of mobile learning: Toward learner-centered education. In Z. L. Berge \& L. Y. Muilenburg (Eds.), Handbook of mobile learning (pp. 3-14). Florence, KY: Routledge.

Dos, B. (2014). The relationship between mobile phone use, metacognitive awareness and academic achievement. European Journal of Educational research, 3(4), 192-200. https://doi.org/10.12973/eu-jer.3.4.192

Elias, T. (2011). Universal instructional design for mobile learning. International Review of Research in Open and Distance Learning, 12(2), 143-156. https://doi.org/10.19173/irrodl.v12i2.965

Fabian, K., Topping, I., Barron, K. (2016). Mobile technology and mathematics: effects on students' attitudes, engagement, and achievement. Journal of Computers in Education, 3(1), 77-104. https://doi.org/10.1007/s40692-015-0048-8

Forcier, R. C. (1996). The computer as a productivity tool in education. US: Prentice Hall Company Press.

Grad, R. M., Pluye, P., Meng, Y., Segal, B., \& Tamblyn, R. (2005). Assessing the impact of clinical information retrieval technology in a family practice residency. Journal of Evaluation in Clinical Practice, 11(6), 576-586. https://doi.org/10.1111/j.1365-2753.2005.00594.x

Garrison, R., \& Cleveland-Innes, M. (2005). Facilitating cognitive presence in online learning: Interaction is not enough. American Journal of Distance Education, 19(3), 133-148. https://doi.org/10.1207/s15389286ajde1903_2

Hawkins, R. (2001). Second language syntax: A generative introduction. Wiley-Blackwell.

Hsu, L. (2013). English as a foreign language learners' perception of mobile assisted language learning: a cross-national study. Computer Assisted Language Learning, 26(3), 197-213. https://doi.org/10.1080/09588221.2011.649485

Jabbour, K. K. (2013). An analysis of the effect of mobile learning on Lebanese higher education. Bulgarian Journal of Science and Education Policy, 7(2), 280-301.

Kim, D., Rueckert, D., Kim, D. J., \& Seo, D. (2013). Student' perceptions and experiences of mobile learning. Language Learning and Technology, 17(3), 52-73.

Levy, M. (2000). Scope, goals and methods in CALL research: questions of coherence and autonomy. ReCALL, 12(2), 170-195. https://doi.org/10.1017/S0958344000000525

Lin, H. C. (2004). Online chatting for EFL writing. Taipei: Crane.

Liou, H. C. (2004). How can we tell others multimedia language education is useful or effective? Multimedia Assisted Learning, 5(1), 122-150.

Liu, L. (2003). A look at the research on computer-based technology use in second language learning. Oxford University Press.

Looi, C. K., \& Wong, L. H. (2014). Implementing mobile learning curricula in schools: A program of research from innovation to scaling. Educational Technology \& Society, 17(2), 72-84.

Mehdipour, Y., \& Zerehkafi, H. (2013). Mobile learning for education: Benefits and challenges. International Journal of Computational Engineering Research, 3(6), 93-101.

Mendoza, G, A. (2014). A comparative study of computer and mobile phone-mediated collaboration: the case of 
Yoon, T.

university students in Japan. International Journal of Educational Technology in Higher Education, 11(1), 222-237.

Moallem, M. (2003). An interactive online course: a collaborative design model. Educational Technology Research and Development, 51(4), 85-103. https://doi.org/10.1007/BF02504545

Motiwalla, L. F. (2007). Mobile learning: A framework and evaluation. Computers \& Education, 49, 581-596. https://doi.org/10.1016/j.compedu.2005.10.011

Nicholson, S. (2002). Socialization in the "virtual hallway": instant messaging in the asynchronous web-based distance education classroom. The Internet and Higher Education, 5(4), 363-372. https://doi.org/10.1016/S1096-7516(02)00127-6

Sharma, S. K., \& Kitchens, F. L. (2004). Web services architecture for M-learning. Electronic Journal on E-Learning, 2(1), 203-216.

Sharples, M. (2000). The design of personal mobile technologies for lifelong learning. Computers and Education 34(3), 177-193. https://doi.org/10.1016/S0360-1315(99)00044-5

Shin, S., \& Kang, M. S. (2015). The use of a mobile learning management system at an online university and its effect on learning satisfaction and achievement. The International Review of Research in Open and Distributed Learning, 16(3), 110-115. https://doi.org/10.19173/irrodl.v16i3.1984

Singh, M. (2010). M-learning: A new approach to learn better. International Journal of Education and Allied Sciences, 2(2), 65-72.

Stead, G., \& Good, M. (2011). Mobile learning in vocational settings: lessons from the E-Ten BLOOM project. In Pachler, N., Pimmer, C., \& Seipold, J. (Eds.), Work-based mobile learning: Concepts and cases (pp. 173-197). New York: Peter-Lang.

Taleb, Z., Ahmadi, A., \& Musavi, M. (2015). The effect of m-learning on mathematics learning. Procedia-Social and Behavioral Sciences, 171, 83-89. https://doi.org/10.1016/j.sbspro.2015.01.092

Tschirner, E. (2001). Language acquisition in the classroom: the role of digital video. Computer Assisted Language Learning, 14(4), 305-319. https://doi.org/10.1076/call.14.3.305.5796

Vilmi, R. (1999). Language Learning Over Distance. Cambridge, England: Cambridge University Press. Vonderwell, S. (2003). An examination of asynchronous communication experiences and perspectives of students in an online course: a case study. Internet and Higher Education, 6, 77-90. https://doi.org/10.1016/S1096-7516(02)00164-1

Wang, M., Shen, R., Novak, D., \& Pan, X. (2009). The impact of mobile learning on students' learning behaviors and performance: Report from a large blended classroom. British Journal of Educational Technology, 40(4), 673-695. https://doi.org/10.1111/j.1467-8535.2008.00846.x

Wang, S. (2006). Computer-assisted language learning (CALL): A case study. Sino-Us English Teaching, 3(9), $17-20$

Yoon, T. (2013). Are you digitized? Ways to provide motivation for ELLs using digital storytelling. International Journal of Research Studies in Educational Technology, 2(1), 1-10. https://doi.org/10.5861/ijrset.2012.204

Yoon, T. (2016). Improving EFL learners' English skills through computer-mediated language strategy. International Journal of Research Studies in Educational Technology, 5(2), 35-48. https://doi.org/10.5861/ijrset.2016.1573

Young, A., \& Norgard, C. (2006). Assessing the quality of online courses from the students' perspective. Internet and Higher Education, 9(1), 107-115. https://doi.org/10.1016/j.iheduc.2006.03.001 